\title{
103 butterflies (Papilionoidea) from Ilha Grande and Ilha da Marambaia, Rio de Janeiro, Brazil
}

\author{
Carlos Eduardo Guimarães Pinheiro ${ }^{1,3}$; Millena Castro Ribeiro ${ }^{1,4}$ \& Roberto de Xerez ${ }^{2,5}$ \\ 1 Universidade de Brasília (UNB), Instituto de Ciências Biológicas (ICB), Departamento de Zoologia. Brasília, DF, Brasil. \\ 2 Universidade Federal Rural do Rio de Janeiro (UFRRJ), Instituto de Ciências Biológicas e da Saúde (ICBS), \\ Departamento de Biologia Animal. Seropédica, RJ, Brasil. \\ ${ }^{3}$ ORCID: http://orcid.org/0000-0001-8675-5647. E-mail: cegp@unb.br \\ ${ }^{4}$ ORCID: http://orcid.org/0000-0001-6305-3482. E-mail: millena.castro2018@gmail.com \\ ${ }^{5}$ ORCID: http://orcid.org/0000-0002-6244-6599. E-mail: rdexerez@gmail.com
}

\begin{abstract}
Here we show a list of 103 butterflies (Papilionoidea) found at llha Grande and Ilha da Marambaia, Rio de Janeiro State, Brazil. To our knowledge, this is the first butterfly inventory conducted in these islands. The species richness, the collecting methods utilized, endemism, and the mimicry rings found in the islands are discussed. Moreover, we emphasize the importance and the utilization of butterflies as suitable models to assess community ecology patterns.
\end{abstract}

Keywords. Atlantic Forest; Coastal Rain Forest; Inventory; Diversity.

\begin{abstract}
Resumo. 103 borboletas (Papilionoidea) da Ilha Grande e Ilha da Marambaia, Rio de Janeiro, Brasil. Neste artigo apresentamos uma lista com 103 borboletas (Papilionoidea) encontradas na llha Grande e llha da Marambaia no Estado do Rio de Janeiro, Brasil. Até onde sabemos este é o primeiro inventário de borboletas realizado nestas ilhas. A riqueza de espécies, os métodos de coleta utilizados, endemismos e os anéis miméticos encontrados em ambas as ilhas são discutidos. Além disto, nos enfatizamos a importância e a utilização de borboletas como modelos na investigação de padrões relacionados à ecologia de comunidades.
\end{abstract}

Palavras-Chave. Floresta Atlântica; Floresta Pluvial Costeira; Inventários; Diversidade.

\section{INTRODUCTION}

The Atlantic Forest is by far the richest biome for butterflies and many other animals in the Neotropics (Brown-Jr. \& Freitas, 2000; Myers et al., 2000; Lamas, 2004). Unfortunately, it is also the most devastated biome in this large region with less than $12 \%$ of its original distribution relatively preserved (Ribeiro et al., 2009). One of the most vulnerable parts of the Atlantic Forest Biome is known as Coastal Rain Forest (Ferri, 1980) that is now restricted to the sides of the Serra do Mar and islands along the Brazilian cost, especially in the Rio de Janeiro State. Ilha Grande (193 km²) and Ilha da Marambaia $\left(81 \mathrm{~km}^{2}\right)$ are among the biggest islands of this region (Fig. 1). The former is isolated from the mainland for about $2 \mathrm{~km}$ and is covered mostly by dense (47\%) and advanced successional stage (43\%) of forests (Alho et al., 2002; Oliveira, 2002; Callado et al., 2009). The latter is not a true island as it is connected to mainland by an extension of about $35 \mathrm{~km}$ of sandbanks covered by restinga vegetation, but also contains a relatively large portion of primary and secondary Coastal Rain Forest (Pereira et al., 1990; Proença et al., 2013). The forest part of Marambaia belongs to the Brazilian Navy and the restricted access contributed to preserve the vegetation.

A great deal of research has been devoted to the identification and characterization of the flora and fauna of both islands (reviewed in Menezes et al., 2005; INEA, 2010). However, we found no information concerning their butterfly faunas. This led us to publish our list of butterflies (Papilionoidea) observed and collected in these islands almost two decades ago (see below). In addition to general comments on the list and the mimicry rings observed, we reinforce the importance of butterflies as suitable models to assess community ecology patterns. 


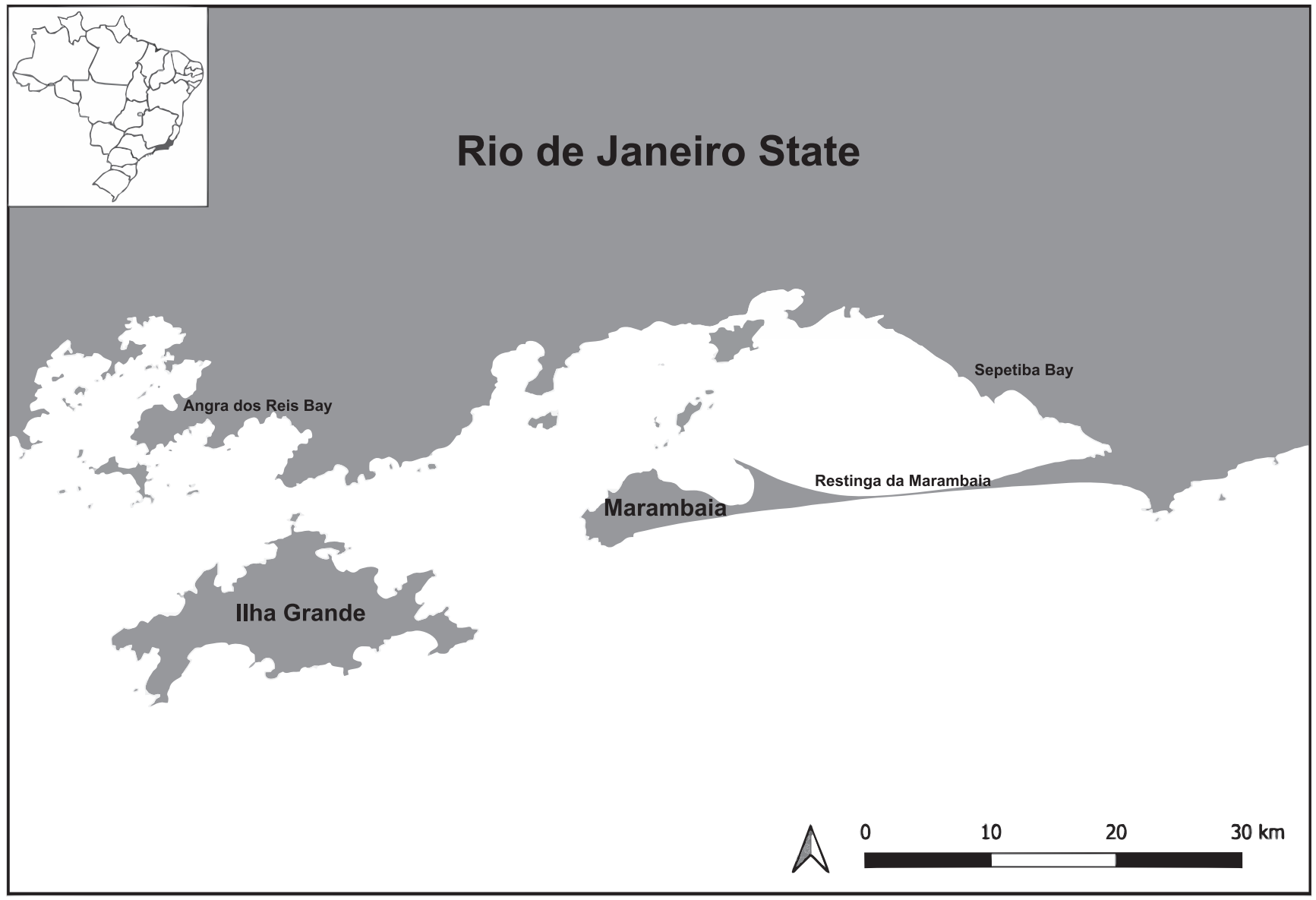

Figure 1. View of Ilha Grande and Ilha da Marambaia, Rio de Janeiro.

\section{MATERIALS AND METHODS}

Rather than a traditional inventory, most butterflies in our list were utilized in a variety of behavioral and ecological didactical projects developed in the "ecology field course" of the University of Brasilia. Field courses at Ilha Grande were conducted in April 8-13, 1996; May 1-9, 1999; and June 3-10, 2001. Representative specimens of the butterflies were collected with entomological nets and/or traps containing baits of banana fermented in sugarcane juice in sites relatively close to the Vila do Abraão $\left(23^{\circ} 08^{\prime} 40.5^{\prime \prime} \mathrm{S} ; 44^{\circ} 10^{\prime} 12.9^{\prime \prime} \mathrm{W}\right)$ on the west side of the island. Field courses at Marambaia were conducted in June 23-29, 2002; May 25-31, 2003; May 9-15, 2004, and May 22-28, 2005. Butterfly collection also involved both methods in sites around the Centro de Adestramento da

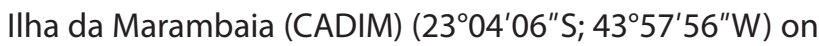
the east side of the island. All butterflies were deposited in the Entomological Collection of the University of Brasília.

\section{RESULTS AND DISCUSSION}

A list of 103 butterflies (Papilionoidea) including 60 species found at Ilha Grande and 85 at Ilha da Marambaia is shown in Table 1. Such a difference between islands is due to differences in sampling intensity and, therefore, does not reflect the actual species richness of butterflies in each island. In fact, we do expect that future surveys will reveal many new records of butterflies in both islands. Most butterflies collected were Nymphalidae $(n=73)$, but representative species of the Papilionidae $(n=3)$, Pieridae $(n=8)$, Lycaenidae $(n=3)$, Riodinidae $(n=2)$, and Hesperiidae $(n=14)$ were also found. The large number of Nymphalidae is due to several projects conducted with the Danainae $(n=18)$ and Heliconiinae $(n=12)$, two taxa that contain many mimetic butterflies that are easily seen and easily collected with entomological nets (part of them is illustrated in Figs. 2-4), as well as projects involving fruit-feeding butterflies. The latter constitutes a guild of adult butterflies that includes several Nymphalinae $(n=6)$, Limenitidinae $(n=2)$, Biblidinae $(n=14)$, Charaxinae $(n=6)$ and Satyrinae $(n=15)$.

Most other taxa remain subsampled. The Pieridae, for instance, is represented by 46 species in continental Rio de Janeiro (Monteiro et al., 2009). Our observations indicate that some of them also occur at Ilha Grande and Ilha da Marambaia. Large and migratory butterflies like Anteos Hübner, [1819] and Phoebis Hubner, [1819] (Coliadinae) were sighted - but not collected, on many different occasions. The Lycaenidae, with 207 species already found in Rio de Janeiro state (Duarte et al., 2009) and the Riodinidae are groups highly represented in the Atlantic Forest and many new records of both groups are expected to occur in future surveys. In the case of 
Table 1. Butterflies (Papilionoidea) found at llha Grande and llha da Marambaia, Rio de Janeiro State, Brazil and their mimicry rings: BRW (= black, red \& white spots); $\mathrm{T}$ (= Tiger); CW (= clear wing); BRY (= black, red \& yellow bar); OBS (= orange \& black stripes). $M M=$ model or Müllerian mimic; BM = Batesian mimic.

\begin{tabular}{|c|c|c|c|c|c|c|c|}
\hline TAXA & $\begin{array}{l}\text { MIMICRY } \\
\text { RINGS }\end{array}$ & $\begin{array}{c}\text { ILHA } \\
\text { GRANDE }\end{array}$ & $\begin{array}{c}\text { MARAM- } \\
\text { BAIA }\end{array}$ & TAXA & $\begin{array}{l}\text { MIMICRY } \\
\text { RINGS }\end{array}$ & $\begin{array}{c}\text { ILHA } \\
\text { GRANDE }\end{array}$ & $\begin{array}{c}\text { MARAM- } \\
\text { BAIA }\end{array}$ \\
\hline PAPILIONIDAE & & & & Actinotesp. & $T-M M$ & $x$ & \\
\hline Papilioninae & & & & Heliconiini & & & \\
\hline Troidini & & & & Dryadula phaetusa (Linnaeus, 1758) & OBS - MM & $x$ & $x$ \\
\hline Battus polydamas polydamas (Linnaeus, 1758) & & $x$ & $X$ & Dryas iulia alcionea (Cramer, 1779) & OBS - MM & $x$ & $x$ \\
\hline Parides tros tros (Fabricius, 1793) & & $x$ & & Dione juno juno (Cramer, 1779) & $\mathrm{OBS}-\mathrm{MM}$ & $x$ & $x$ \\
\hline Parides anchises nephalion (Godart, 1819) & BRW - MM & $x$ & $x$ & Eueides aliphera aliphera (Godart, 1819) & $O B S-M M$ & $x$ & $x$ \\
\hline PIERIDAE & & & & Heliconius erato phyllis (Fabricius, 1775) & $B R Y-M M$ & $x$ & $x$ \\
\hline Dismorphiinae & & & & Heliconius ethilla narcaea (Godart, 1819) & $\mathrm{T}-\mathrm{MM}$ & $x$ & $x$ \\
\hline Dismorphia amphione astynome (Dalman, 1823) & $\mathrm{T}-\mathrm{BM}$ & $x$ & $x$ & Heliconius numata robigus (Weymer, 1875) & $\mathrm{T}-\mathrm{MM}$ & $x$ & \\
\hline Coliadinae & & & & Heliconius sara apseudes (Hübner, [1813]) & & $x$ & $x$ \\
\hline Eurema elathea flavescens (Chavannes, 1850) & & $x$ & $x$ & Limenitidinae & & & \\
\hline Eurema albula sinoe (Godart, 1819) & & $x$ & & Limenitidini & & & \\
\hline Pyrisitia leuce leuce (Boisduval, 1836) & & & $x$ & Adelpha cytherea aea (C. Felder \& R. Felder, 1867) & & $x$ & $x$ \\
\hline Leucidia elvina (Godart, 1819) & & & $x$ & Adelpha plesaure phliassa (Godart, [1824]) & & & $x$ \\
\hline Phoebis philea philea (Linnaeus, 1763) & & $x$ & & Biblidinae & & & \\
\hline Pierinae & & & & Biblidini & & & \\
\hline Pierini & & & & Biblis hyperia nectanabis (Fruhstorfer, 1909) & & $x$ & $x$ \\
\hline Ascia monuste orseis (Godart, 1819) & & $x$ & $X$ & Catonephelini & & & \\
\hline Archonias brassolis tereas (Godart, 1819) & $\mathrm{BRW}-\mathrm{BM}$ & $x$ & & Catonephele acontius caeruleus Jenkins, 1985 & & & $x$ \\
\hline LYCAENIDAE & & & & Myscelia orsis (Drury, 1782) & & $x$ & $x$ \\
\hline Theclinae & & & & Ageroniini & & & \\
\hline Eumaeini & & & & Ectima thecla thecla (Fabricius, 1796) & & & $x$ \\
\hline Pseudolycaena marsyas (Linnaeus, 1758) & & $x$ & $x$ & Hamadryas amphinome amphinome (Linnaeus, 1767) & & & $x$ \\
\hline Pseudolycaena marsyas (Linnaeus, 1/38) & & $\begin{array}{l}x \\
x\end{array}$ & $x$ & Hamadryas februa (Hübner, [1823]) & & $x$ & $x$ \\
\hline $\begin{array}{l}\text { Strymon mulucha (Hewitson, 186/) } \\
\text { Panthiades nhaleros (linnaevs 1767) }\end{array}$ & & $X$ & & Hamadryas feronia feronia (Linnaeus, 1758) & & $x$ & $x$ \\
\hline $\begin{array}{l}\text { Panthiades phaleros (Linnaeus, 1767) } \\
\text { RIODINIDAF }\end{array}$ & & & $X$ & Epiphilini & & & \\
\hline RIODINIDAE & & & & Nica flavilla flavilla (Godart, [1824]) & & & $x$ \\
\hline Riodininae & & & & Eubagini & & & \\
\hline Mesosemiini & & & & Dynamine agacles agacles (Dalman, 1823) & & & $x$ \\
\hline Leucochimona icare matatha (Hewitson, 1873) & & & $x$ & Dynamine artemisia artemisia (Fabricius, 1793) & & $X$ & $x$ \\
\hline Nymphidiini & & & & Dynamine athemon maeon (E. Doubleday, 1849) & & $x$ & $x$ \\
\hline Nymphidium lisimon (Stoll, 1790) & & & $x$ & Dynamine postverta postverta (Cramer, 1779) & & & $x$ \\
\hline NYMPHALIDAE & & & & Callicorini & & & \\
\hline Danainae & & & & Haematera pyrame pyrame (Hübner, [1819]) & & & $x$ \\
\hline Danaini & & & & Diaethria clymena janeira (C. Felder, 1862) & & $x$ & $x$ \\
\hline Lycorea halia discreta Haensch, 1909 & $\mathrm{~T}-\mathrm{MM}$ & $x$ & $x$ & Nymphalinae & & & \\
\hline Danaus gilippus gilippus (Cramer, 1775) & & & $x$ & Coeini & & & \\
\hline Ithomiini & & & & Historis odius odius (Fabricius, 1775) & & & $x$ \\
\hline Aeria olena olena Weymer, 1875 & & & $x$ & Victorinini & & & \\
\hline Melinaea ethra (Godart, 1819) & $\mathrm{T}-\mathrm{MM}$ & $x$ & $x$ & Anartia amathea roeselia (Eschscholtz, 1821) & & & $x$ \\
\hline Melinaea Iudovica paraiya Reakirt, 1866 & $\mathrm{~T}-\mathrm{MM}$ & $x$ & $x$ & Anartia jatrophae jatrophae (Linnaeus, 1763) & & $x$ & $x$ \\
\hline Mechanitis lysimnia lysimnia (Fabricius, 1793) & $\mathrm{T}-\mathrm{MM}$ & $x$ & $x$ & Melitaeini & & & \\
\hline Mechanitis polymnia casabranca Haensch, 1905 & $\mathrm{~T}-\mathrm{MM}$ & $x$ & $x$ & Eresia eunice esora Hewitson, 1857 & $\mathrm{~T}-\mathrm{BM}$ & $x$ & \\
\hline Hypothyris ninonia daeta (Boisduval, 1836) & $\mathrm{T}-\mathrm{MM}$ & $x$ & $x$ & Eresia lansdorfi (Godart, 1819) & $B R Y-B M$ & $x$ & $x$ \\
\hline Ithomia agnosia zikani R.F. D'Almeida, 1940 & $\mathrm{CW}-\mathrm{MM}$ & $x$ & $x$ & Tegosa claudina (Eschscholtz, 1821) & & $x$ & $x$ \\
\hline Ithomia drymo Hübner, 1816 & $\mathrm{CW}-\mathrm{MM}$ & $x$ & $x$ & Charaxinae & & & \\
\hline Oleria aquata (Weymer, 1875) & & $x$ & $x$ & Anaeini & & & \\
\hline Episcada striposis Haensch, 1909 & $\mathrm{CW}-\mathrm{MM}$ & $x$ & $x$ & Consul fabius drurii (Butler, 1874) & $T-B M$ & $x$ & $x$ \\
\hline Episcada hymenaea hymenaea (Prittwitz, 1865) & $\mathrm{CW}-\mathrm{MM}$ & $x$ & & Hypna clytemnestra ssp. & & $x$ & $x$ \\
\hline Pteronymia euritea (Cramer, 1780) & $\mathrm{CW}-\mathrm{MM}$ & $x$ & & Siderone galanthis (Cramer, 1775) & & & $x$ \\
\hline Mcclungia cymo salonina (Hewitson, 1855) & $\mathrm{CW}-\mathrm{MM}$ & $x$ & & Fountainea ryphea phidile (Geyer, 1837) & & & $x$ \\
\hline Heterosais edessa (Hewitson, [1855]) & $\mathrm{CW}-\mathrm{MM}$ & $x$ & & Memphis moruus stheno (Prittwitz, 1865) & & & $x$ \\
\hline Pseudoscada acilla acilla (Hewitson, 1867) & CW - MM & $x$ & $x$ & Preponini & & & \\
\hline Pseudoscada erruca (Hewitson, 1855) & CW - MM & $x$ & & Archaeoprepona demophon thalpius (Hübner, [1814]) & & $x$ & $x$ \\
\hline Heliconiinae & & & & Satyrinae & & & \\
\hline Acraeini & & & & Morphini & & & \\
\hline Actinote carycina Jordan, 1913 & $\mathrm{~T}-\mathrm{MM}$ & & $x$ & Morpho helenor achillaena (Hübner, [1823]) & & $x$ & $x$ \\
\hline Actinote parapheles Jordan, 1913 & $T-M M$ & $x$ & & Brassolini & & & \\
\hline Actinote pellenea pellenea Hübner, [1821] & $\mathrm{T}-\mathrm{MM}$ & $x$ & $x$ & Caligo brasiliensis brasiliensis (C. Felder, 1862) & & & $x$ \\
\hline
\end{tabular}




\begin{tabular}{|c|c|c|c|}
\hline TAXA & $\begin{array}{l}\text { MIMICRY } \\
\text { RINGS }\end{array}$ & $\begin{array}{l}\text { ILHA } \\
\text { GRANDE }\end{array}$ & $\begin{array}{c}\text { MARAM- } \\
\text { BAIA }\end{array}$ \\
\hline Eryphanis automedon automedon (Cramer, 1775) & & & $x$ \\
\hline Opsiphanes invirae amplificatus Stichel, 1904 & & & $x$ \\
\hline \multicolumn{4}{|l|}{ Satyrini } \\
\hline Chloreuptychia herseis (Godart, [1824]) & & & $x$ \\
\hline Amiga arnaca arnaca (Fabricius, 1776) & & & $x$ \\
\hline Cissia myncea (Cramer, 1780) & & & $x$ \\
\hline Cissia phronius (Godart, [1824]) & & & $\mathrm{x}$ \\
\hline Godartiana muscosa (A. Butler, 1870) & & & $x$ \\
\hline Hermeuptychia sp. 1 & & & $x$ \\
\hline Hermeuptychia sp. 2 & & & $x$ \\
\hline "Paryphthimoides"aff. sylvina & & & $x$ \\
\hline Pareuptychia ocirrhoe interjecta (R.F. D’Almeida Imeida, 1952) & & $\mathrm{x}$ & $x$ \\
\hline Posttaygetis penelea (Cramer, 1777) & & & $\mathrm{x}$ \\
\hline Taygetis virgilia (Cramer, 1776) & & & $x$ \\
\hline \multicolumn{4}{|l|}{ HESPERIIDAE } \\
\hline \multicolumn{4}{|l|}{ Eudaminae } \\
\hline Urbanus proteus proteus (Linnaeus, 1758) & & & $\mathrm{x}$ \\
\hline Urbanus esmeraldus (A. Butler, 1877) & & $\mathrm{x}$ & \\
\hline
\end{tabular}

\begin{tabular}{|c|c|c|c|}
\hline TAXA & $\begin{array}{l}\text { MIMICRY } \\
\text { RINGS }\end{array}$ & $\begin{array}{l}\text { ILHA } \\
\text { GRANDE }\end{array}$ & $\begin{array}{c}\text { MARAM- } \\
\text { BAIA }\end{array}$ \\
\hline Urbanus teleus (Hübner, 1821) & & $x$ & $x$ \\
\hline Urbanus procne (Plötz, 1881) & & & $x$ \\
\hline Urbanus virescens (Mabille, 1877) & & $x$ & \\
\hline Astraptes fulgerator fulgerator (Walch, 1775) & & & $x$ \\
\hline Autochton zarex (Hübner, 1818) & & & $x$ \\
\hline Spathilepia clonius (Cramer, 1775) & & & $x$ \\
\hline \multicolumn{4}{|l|}{ Pyrginae } \\
\hline \multicolumn{4}{|l|}{ Erynnini } \\
\hline Mylon ander ander Evans, 1953 & & $x$ & \\
\hline \multicolumn{4}{|l|}{ Pyrgini } \\
\hline Trina geometrina geometrina (C. Felder\& R. Felder, 1867) & & & $x$ \\
\hline Pyrgus oileus (Linnaeus, 1767) & & & $x$ \\
\hline \multicolumn{4}{|l|}{ Hesperiinae } \\
\hline \multicolumn{4}{|l|}{ Calpodini } \\
\hline Talides riosa Evans, 1955 & & & $x$ \\
\hline Calpodes ethlius (Stoll, 1782) & & $x$ & \\
\hline \multicolumn{4}{|l|}{ Moncini } \\
\hline Callimormus corades (C. Felder, 1862) & & & $x$ \\
\hline
\end{tabular}
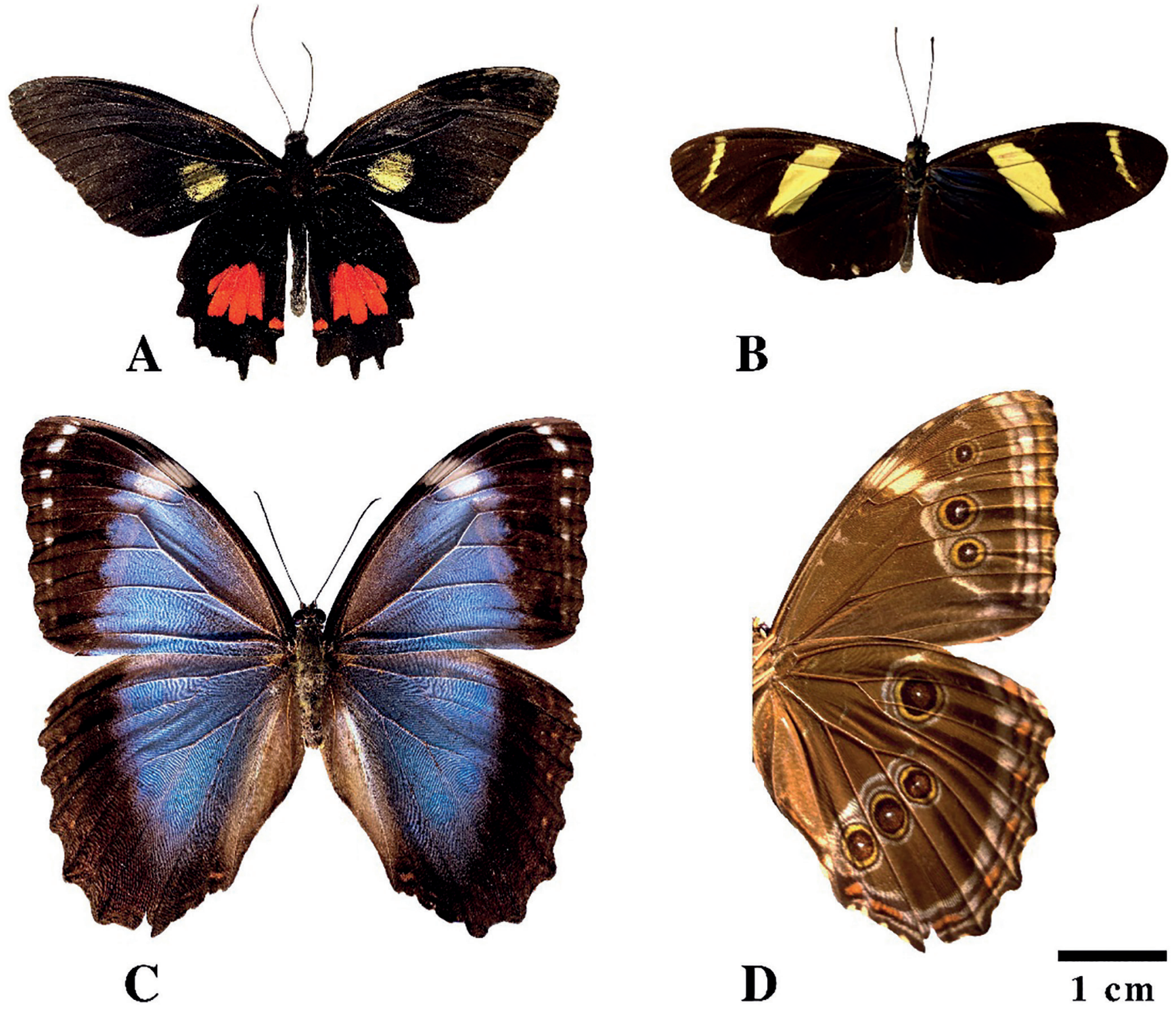

Figure 2. Endemic Atlantic Forest butterflies (A-B) and a local morph (C-D). (A) Parides tros tros; (B) Heliconius sara apseudes; (C-D) Morpho helenor achillaena (dorsal $\&$ ventral view). All individuals are males. 
Marambaia, the restinga region has never been sampled or visited. Recent observations indicate that restinga habitats usually contain a variety of Riodinidae, Lycaenidae and Hesperiidae species (A.V.L. Freitas pers. comm.).

\section{Endemic butterflies}

Many butterflies in Table 1 are widespread in Brazil occurring in the Cerrado (Emery et al., 2006; Mielke et al., 2008), the Amazon and other Neotropical regions
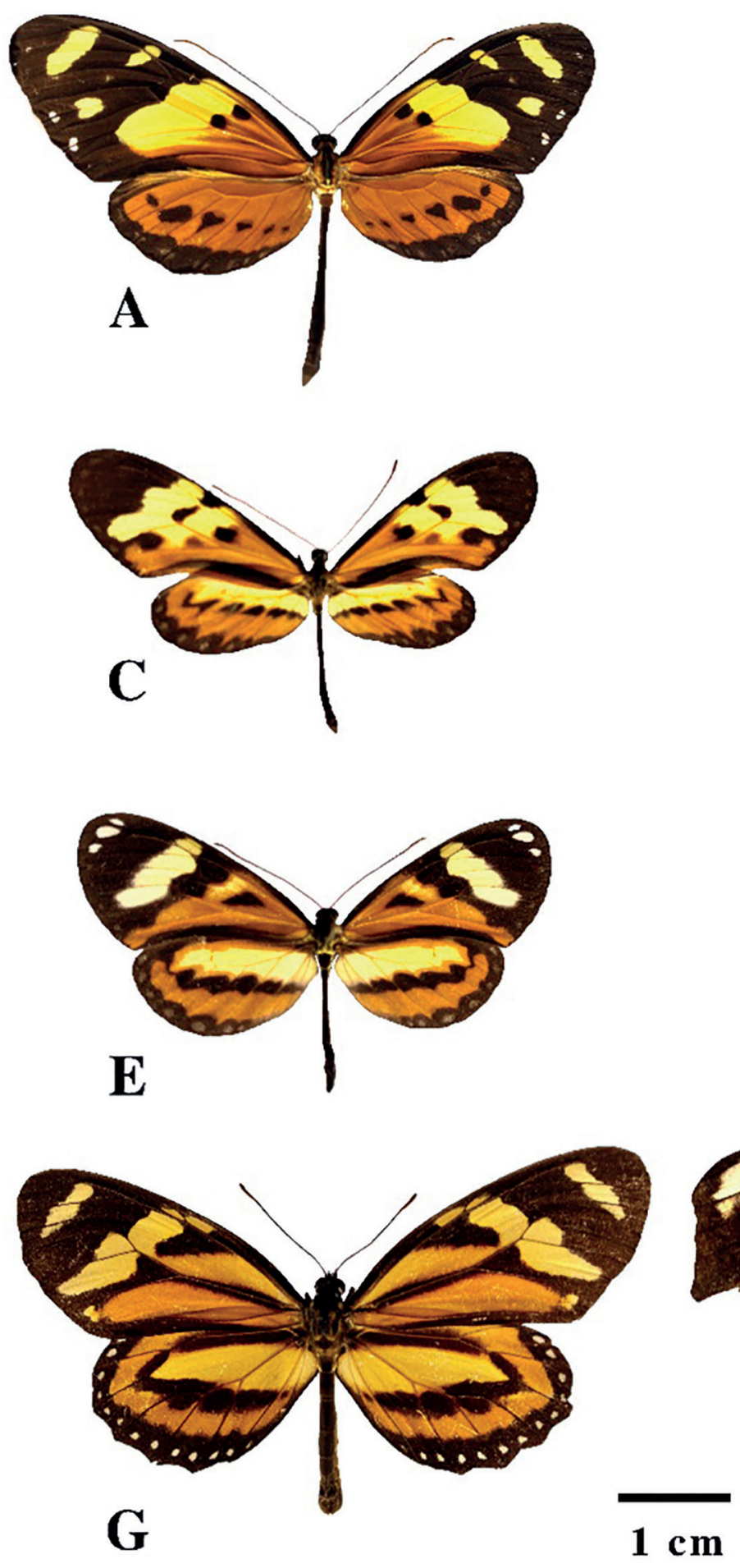

Figure 3. The Tiger mimicry ring (A-H): (A) Melinaea ludovica paraiya, male; (B) Melinaea ethra, female; (C) Mechanitis polymnia casabranca, male; (D) Mechanitis lysimnia lysimnia, female; (E) Hypothyris ninonia daeta, female; (F) Heliconius ethilla narcaea, male; (G) Lycorea halia discreta, male; (H) Consul fabius drurii, male.
(Lamas, 2004). However, at least two examples of endemic Atlantic Forest butterflies were found, including Parides tros tros (Fabricius, 1793) (Fig. 2A) that is restricted to coastal forests and mountains along the Serra do Mar (Tyler et al., 1994), and Heliconius sara apseudes (Hübner, [1813]) (Fig. 2B) that occurs from the Brazilian northeast to the Rio Grande do Sul State (Brown-Jr., 1992; Iserhard et al., 2010). Another example we believe that could constitute a potential case of endemism is the large, eye catching Morpho helenor achillaena (Hübner, [1823]) (Fig. 2C). In contrast to other regions where this
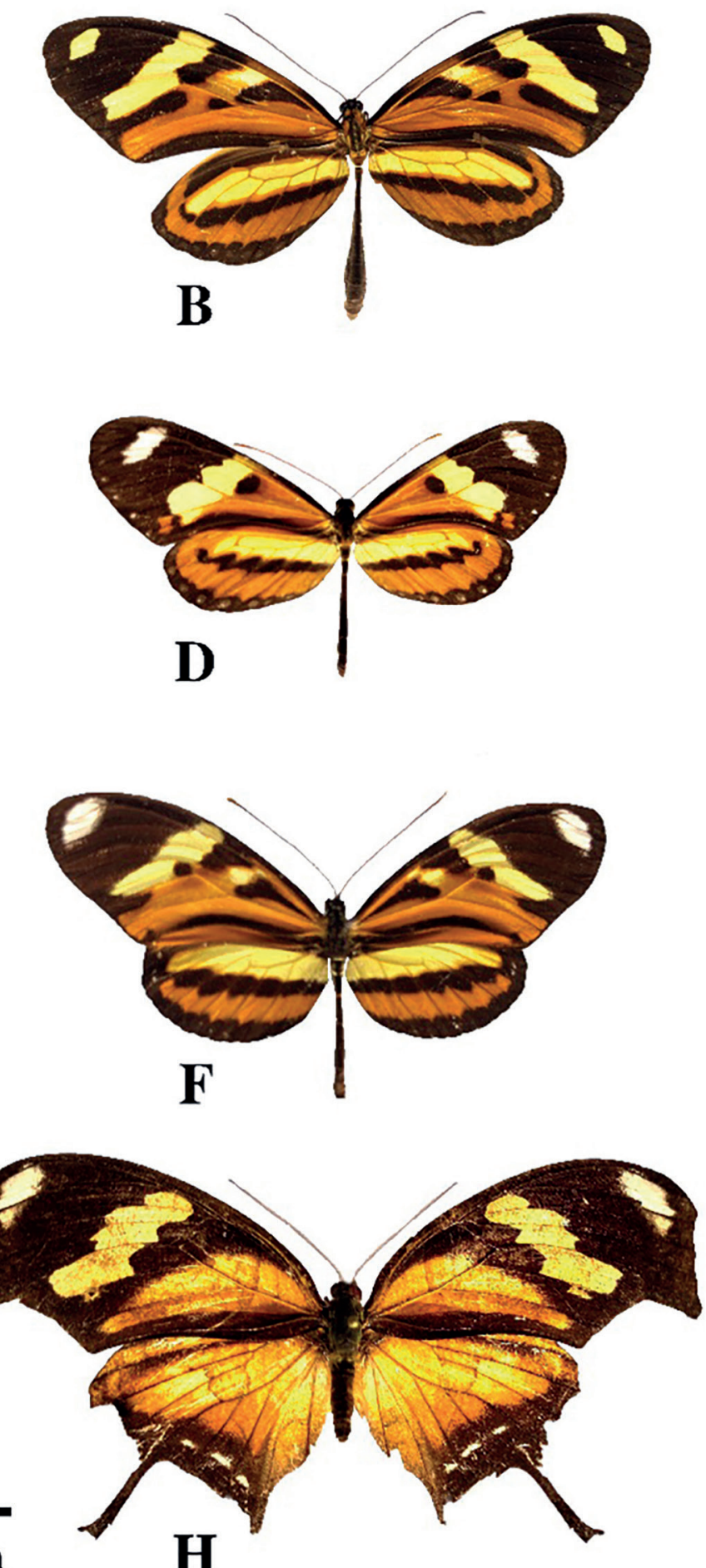

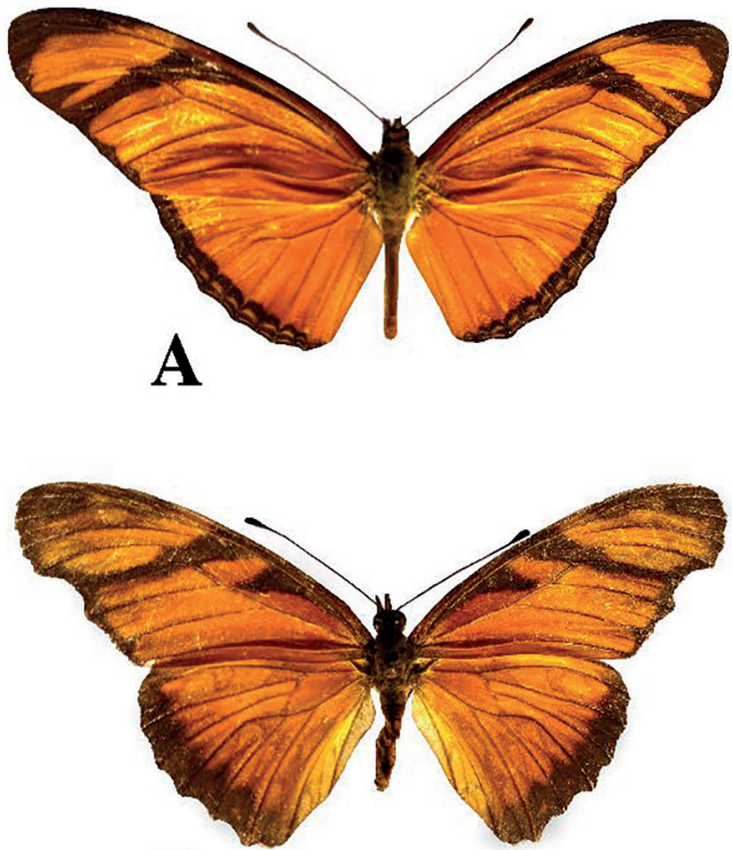

B

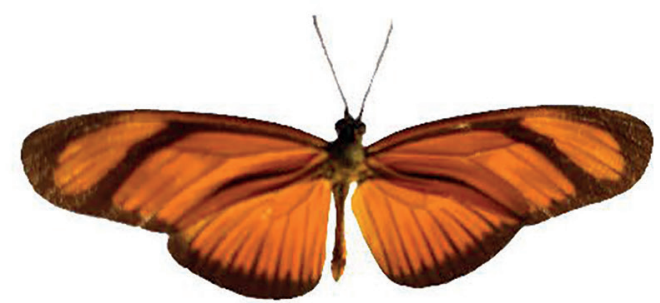

C
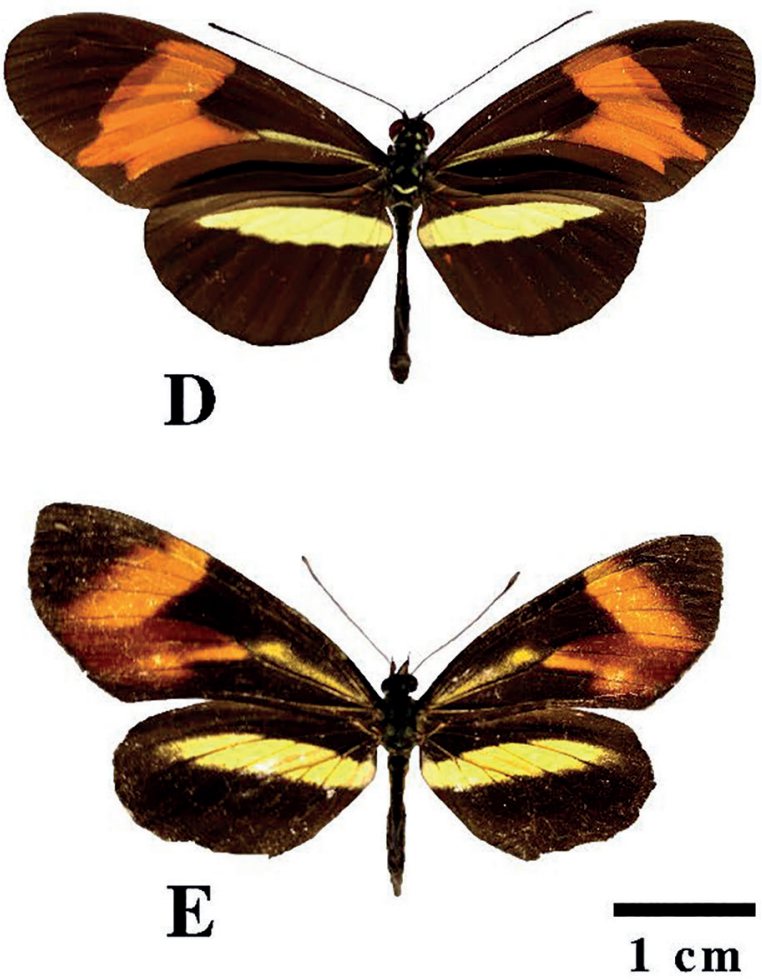

Figure 4. The Orange \& Black striped $(A-C)$ and the Black, Red \& Yellow mimicry rings (D-E). (A) Dryas iulia alcionea, female; (B) Dione juno juno, male; (C) Eueides aliphera aliphera, male; (D) Heliconius erato phyllis, male; (E) Eresia lansdorfi, male. butterfly occurs, most individuals - especially males show an intense iridescent blue coloration in the medium and, unexpectedly, the inner parts of the upper wings, and also differ in traits on the ventral wing surface (Fig. 2D) like the number of eyespots and other morphological traits usually considered in the systematic of Morpho Fabricius, 1807 (Penz et al., 2012). Melinaea ludovica paraiya Reakirt, 1866 (Fig. 3A) has been also regarded as an Atlantic Forest butterfly occurring along the Atlantic coastline from Santa Catarina to the Rio de Janeiro (Lamas, 2004). However, recent observations indicate this butterfly reaches the Pernambuco State in northeast Brazil and more rarely also occurs in gallery forests in the cerrado vegetation of Minas Gerais (A.V.L. Freitas, pers. comm.). Finally, many other cases of endemism are expected to occur as new surveys and systematic studies are concluded, including the species or subspecies of Hermeuptychia sp. 1, Hermeuptychia sp. 2, and "Paryphthimoides" aff. sylvina whose systematic remains poorly understood.

\section{Mimicry rings}

Among the butterflies more abundant and easily observed in both islands are several aposematic (i.e., unpalatable and warning colored) and mimetic species that participate in a variety of mimicry rings, i.e., groups of similar looking butterflies usually containing several unpalatable, Müllerian mimics, a phenomenon believed to speed up avoidance learning in predators (Müller, 1879) and one or few palatable, Batesian mimics that mimic the unpalatable species (or models) to deceive predators (Bates, 1862; see Trigo, 2000 for a review of defensive chemicals in Neotropical butterflies).

One of the most common rings partially found in both islands (Table 1) is the "Tiger" mimicry ring that contains several unpalatable Ithomiini, like Melinaea ludovica paraiya (Fig. 3A), Melinaea ethra (Godart, 1819) (Fig. 3B), Mechanitis polymnia casabranca Haensch, 1905 (Fig. 3C), Mechanitis lysimnia lysimnia (Fabricius, 1793) (Fig. 3D), and Hypothyris ninonia daeta (Boisduval, 1836) (Fig. 3E); two Heliconiini, Heliconius ethilla narcaea (Godart, 1819) (Fig. 3F) and Heliconius numata robigus Weimer, 1875; one Danaini, Lycorea halia discreta Haensch, 1909 (Fig. 3G) and the palatable, not chemically defended Consul fabius drurii (Butler, 1874) (Charaxinae; Fig. 3H), Eresia eunice esora Hewitson, 1857 (Melitaeini), and Dismorphia amphione astynome (Dalman, 1823) (Dismorphinae). Brown-Jr. \& Benson (1974) include the Actinote Hubner, [1819] species as part of this ring, but we believe they constitute a ring apart.

Another ring containing numerous unpalatable Ithomiini is the "clear wing" mimicry ring that includes several species of Ithomia Hübner, 1816, Episcada Godman \& Salvin, 1880, Pteronymia Butler \& Druce, 1872, Mcclungia Fox, 1940, Heterosais Godman \& Salvin, 1880, and Pseudoscada Godman \& Salvin, 1879 (Table 1). These butterflies live mostly in shady habitats inside the forest and the species composition of the ring often changes in different islands and sites. 
The "Orange \& Black stripes" ring is also common and easily seen in both islands. It is composed by several moderately unpalatable Heliconiini (Pinheiro, 1996) including: Dryas iulia alcionea (Cramer, 1779) (Fig. 4A), Dione juno juno (Cramer, 1779) (Fig. 4B), Eueides aliphera aliphera (Godart, 1819) (Fig. 4C), and Dryadula phaetusa (Linnaeus, 1758). These butterflies occur mostly in open and sunny sites.

Other rings like the "Black, Red \& Yellow" and the "Black, Red \& White" are represented by only one unpalatable model, respectively, Heliconius erato phyllis (Fabricius, 1775) (Fig. 4D) and Parides anchises nephalion (Godart, 1819), and one Batesian mimic, respectively Eresia lansdorfi (Godart, 1819) (Fig. 4E) and Archonias brassolis tereas (Godart, 1819). Heliconius erato phyllis is by far the most abundant butterfly in both islands. It is easily seen in trails and along the forest border. In the Atlantic region it usually occurs along with the co-mimetic Heliconius melpomene nanna Stichel, 1899 and, more rarely, Heliconius besckei Ménétriés, 1857, but these butterflies were not found in our surveys.

Other aposematic butterflies like Heliconius sara apseudes (Hübner, 1806) (Fig. 1B), Battus polydamas polydamas (Linnaeus, 1758), and Danaus gilippus gilippus (Cramer, 1775) also participate as models or Müllerian mimics in other Atlantic Forest, Cerrado, and Amazon mimicry rings (see examples in Brown-Jr., 1992), but remain as unique representatives of their rings at Ilha Grande and Ilha da Marambaia. We do expect, however, that widespread species that mimic Danaus gilippus gilippus in the "Monarch" mimicry ring like Danaus erippus (Cramer, 1775) and Danaus eresimus plexaure (Godart, 1819) shall appear in future surveys. Other butterflies, like Adelpha cytherea aea (C. Felder \& R. Felder, 1867), Adelpha plesaure phliassa (Godart, [1824]), Hypna clytemnestra ssp., Archaeoprepona demophon thalpius (Hübner, [1814]) and several Hesperiidae species are believed to participate in mimicry rings not based on unpalatability, but on their ability to escape predator attacks (reviewed in Pinheiro \& Freitas, 2014). Such a possibility, however, has not been fully demonstrated and accepted by many authors.

In contrast to most aposematic Nymphalidae that visit flowers for nectar and, more rarely, pollen feeding (such as Heliconius; Brown-Jr., 1992), many other Nymphalidae species feed on sap and rotting fruits. They are often palatable (Pinheiro, 1996, 2007) and show cryptic coloration on both wing sides, e.g., Hamadryas februa (Hübner, [1823]), Hamadryas feronia feronia (Linnaeus, 1758), and the Satyrinae species, or at least on the underside wings, e.g., Biblis hyperia nectanabis (Fruhstorfer, 1909), Catonephele acontius caeruleus Jenkins, 1985 Siderone galanthis (Cramer, 1775) that render them cryptic at rest, with closed wings. Some of these butterflies also became Batesian mimics, e.g., Consul fabius drurii (Butler, 1874) (Fig. 3H). This guild of fruit-feeding butterflies has been utilized in a variety of comparative studies on butterfly communities (e.g., Pinheiro \& Ortiz, 1992; DeVries \& Walla, 2001; Uehara-Prado et al., 2007), as well as in monitoring programs to evaluate habitat quality over time (reviewed in Santos et al., 2016).

\section{CONCLUSIONS}

Ilha Grande and Ilha da Marambaia still preserve important parts of the original Coastal Rain Forest and show a high diversity of butterflies. It is important to emphasize that our 103 butterfly list contains mostly the more abundant and widespread species. We suggest and encourage that future inventories in both islands incorporate other regions and periods of the year that remain uninvestigated. In addition to important and interesting investigations concerning endemism, mimicry and color pattern related phenomena, we suggest that butterflies are also utilized in monitoring programs relative to habitat quality and species diversity. These programs should be applied to both islands, but especially to Ilha Grande that contains a reserve, Parque Estadual da Ilha Grande, created in 1971 (but implemented in 2007), that naturally requires monitoring programs for conservation. In the long term, butterfly inventories should ideally include other small and medium size islands in the Sepetiba and the Angra dos Reis bay to investigate other important community ecology patterns such as species-area relationships and test the supposed equilibrium between colonization and extinction rates of species (MacArtur \& Wilson, 1967) that remains virtually untested for most invertebrates.

\section{ACKNOWLEDGEMENTS}

We are grateful to Dr Thamara Zacca, Dr Mirna M. Casagrande and Dr André Victor Lucci Freitas for the identification of several species. The latter also furnished helpful comments on a previous version of the manuscript. We also thank P.C. Motta and E.O. Emery for field assistance at Ilha Grande and Marambaia, Nilton M. Salgado and Wilson L. Lima (CADIM) for permissions and facilities at Marambaia.

\section{REFERENCES}

Alho, C.J.R.; Schneider, M. \& Vasconcellos, L.A. 2002. Degree of threat to the biological diversity in the llha Grande State Park (RJ) and guidelines for conservation. Brazilian Journal of Biology, 62(3): 375-385. D01

Bates, H.W. 1862. Contributions to an insect fauna of the Amazon valley. Transactions of the Linnean Society of London, 23: 495-566.

Brown-Jr., K.S. 1992. Borboletas da Serra do Japi: diversidade, habitats, recursos alimentares e variação temporal. In: Morelato, L.P.C. (Org.). História natural da Serra do Japi: ecologia e preservação de uma área florestal no sudeste do Brasil. Campinas, Editora da UNICAMP/FAPESP. p. 142-187.

Brown-Jr., K.S. \& Benson, W.W. 1974. Adaptive polymorphism associated with multiple Mullerian mimicry in Heliconius numata (Lepidoptera: Nymphalidae). Biotropica, 6(4): 205-228.

Brown-Jr., K.S. \& Freitas, A.V.L. 2000. Atlantic Forest butterflies: indicators for landscape conservation. Biotropica, 32(4b): 934-956.

Callado, C.H.; Barros, A.A.M.; Ribas, L.A.; Albarello, N.; Gagliardi, R. \& Jascone, C.E.S. 2009. Flora e cobertura vegetal. In: Bastos, M. \& Callado, C.H. (Orgs.). 0 ambiente da llha Grande. Rio de Janeiro, UERJ/CEADS. p. 91-162. 
DeVries, P.J. \& Walla, T.R. 2001. Species diversity and community structure in Neotropical fruit-feeding butterflies. Biological Journal of the Linnean Society, 74(1): 1-15.

Duarte, M.; Robbins, R.K.; Freitas, A.L.V.; Brown-Jr., K.S.; Monteiro, R.F.; Casagrande, M.M.; Mielke, 0.H.H.; Nascimento, M.S. \& Alves, T.G. 2009. Borboletas da Mata Atlântica do Estado do Rio de Janeiro: Lycaenidae (Lepidoptera). Arquivos do Museu Nacional, Rio de Janeiro, 67(3-4): 291-302.

Emery, E.0.; Brown-Jr., K.S. \& Pinheiro, C.E.G. 2006. As borboletas (Lepidoptera, Papilionoidea) do Distrito Federal, Brasil. Revista Brasileira de Entomologia, 50: 85-92.

Ferri, M.G. 1980. Vegetação Brasileira. Belo Horizonte, Editora Itatiaia 157p. Instituto Estadual do Ambiente (INEA). 2010. Parque Estadual da Ilha Grande (PEIG). Rio de Janeiro. Instituto Estadual do Ambiente, Available: http:// www.inea.ri.gov.br/publicacoes/sobre-a-pesquisa-cientifica-nas-ucs/ pesquisas-e-publicacoes/parque-estadual-da-ilha-grande. Access: 15/04/2020.

Iserhard, C.A.; Silva, A.K.; Quadros, M.T.; Castro, D.S. \& Romanowski, H.P. 2010. Lepidoptera, Nymphalidae, Heliconiinae, Heliconius sara apseudes (Hubner, 1813): distribution extension. Check List, 6(2): 316-318.

Lamas, G. 2004. Checklist: Part 4A. Hesperioidea - Papilionoidea. In: Heppner, J.B. (Ed.). Atlas of Neotropical Lepidoptera 5A. Gainesville, Association for Tropical Lepidoptera, Scientific Publishers. 439p.

MacArtur, R. \& Wilson, E.0. 1967. Theory of island biogeography. Princeton, Princeton University Press. 203p.

Menezes, L.F.T.; Peixoto, A.L. \& Araújo, D.S.D. 2005. História Natural da Marambaia. Rio de Janeiro, Editora da Universidade Federal Rural do Rio de Janeiro (EDUR). 288p.

Mielke, 0.H.H.; Emery, E.0. \& Pinheiro, C.E.G. 2008. Hesperiidae (Lepidoptera, Hesperioidea) do Distrito Federal. Revista Brasileira de Entomologia, 52(2): 283-288.

Monteiro, R.R.; Freitas, A.V.L.; Costa-Filho, M.A.F.; Nascimento, M.S.; Alves, T.G.; Brown-Jr., K.S.; Mielke, O.H.H.; Casagrande, M.M. \& Duarte, M. 2009. Borboletas da Mata Atlântica do Estado do Rio de Janeiro: Pieridae (Lepidoptera). Arquivos do Museu Nacional, 67(3-4): 283-289.

Müller, F. 1879. Ituna and Thyridia: a remarkable case of mimicry in butterflies. Proceedings of the Royal Entomological Society of London, 1879: xx-xxix.

Myers, N.; Mittermeier, R.A.; Mittermeier, C.G.; Fonseca, G.A.B. \& Kent, J. 2000. Biodiversity hotspots for conservation priorities. Nature, 403(6772): 853-858.
Oliveira, R.R. 2002. Ação antrópica e resultantes sobre a estrutura e composição da Mata Atlântica na Ilha Grande, RJ. Rodriguésia, 53(82): 33-58. D0I

Penz, C.;DeVries, P.J.\&Wahlberg, N. 2012. Diversification of Morpho butterflies (Lepidoptera, Nymphalidae); a re-evaluation of morphological characters and new insight from DNA sequence data. Systematic Entomology, 37(4): 670-685.

Pereira, L.P.; Xerez, R. \& Pereira, A.M.C. 1990. Ilha da Marambaia (Baía de Sepetiba, RJ): Resumo fisiográfico, histórico e importância ecológica atual. Ciência e Cultura, São Paulo, 42(5/6): 384-389.

Pinheiro, C.E.G. 1996. Palatability and escaping ability in neotropical butterflies: tests with wild kingbirds (Tyrannus melancholicus, Tyrannidae). Biological Journal of the Linnean Society, 59(4): 351-365.

Pinheiro, C.E.G. 2007. Asynchrony in daily activity patterns of butterfly models and mimics. Journal of Tropical Ecology, 23(1): 119-123.

Pinheiro, C.E.G. \& Freitas, A.V.L. 2014. Some possible cases of escape mimicry in Neotropical butterflies. Neotropical Entomology, 43(5): 393-398.

Pinheiro, C.E.G. \& Ortiz, J.V.C. 1992. Communities of fruit-feeding butterflies along a vegetation gradient in central Brazil. Journal of Biogeography, 19(5): 505-511.

Proença, I.; Conde, M.; Gonçalves, N.B.; Figueiredo, P.H.A. \& Rajão, P.H.M. 2013. Árvores da llha da Marambaia. Rio de Janeiro, Technical Books. $286 \mathrm{p}$.

Ribeiro, M.C.; Metzger, J.P.; Martensen, A.C..; Ponzoni, F.J. \& Hirota, M.M. 2009. The Brazilian Atlantic Forest: how much is left, and how is the remaining forest distributed? Implications for conservation. Biological Conservation, 142: 1141-1153.

Santos, J.P.; Marini-Filho, 0.J.; Freitas, A.V.L. \& Uehara-Prado, M. 2016. Monitoramento de borboletas: o papel de um indicador biológico na gestão de unidades de conservação. Biodiversidade Brasileira, 6(1): 87-99.

Trigo, J.R. 2000. The chemistry of antipredator defense by secondary compounds in Neotropical Lepidoptera: facts, perspectives and caveats. Journal of Brazilian Chemical Society, 11(6): 551-561.

Tyler, H.A.; Brown-Jr., K.S. \& Wilson, K.W. 1994. Swallowtail butterflies of the Americas: a study in biological dynamics, ecological diversity, biosystematics and conservation. Gainesville, Scientific Publishers. 376p.

Uehara-Prado, M.; Brown-Jr., K.S. \& Freitas, A.V.L. 2007.Species richness, composition and abundance of fruit-feeding butterflies in the Brazilian Atlantic Forest: comparison between a fragmented and a continuous landscape. Global Ecology and Biogeography, 16: 43-54. D0I 